\title{
Eksplorasi kemampuan penalaran dan representasi matematis siswa sekolah menengah pertama
}

\author{
Absorin Absorin $^{1}$ *, Sugiman Sugiman ${ }^{2}$ \\ ${ }^{1}$ SMP NU Wanasari Kabupaten Indramayu, Wanasari, Bangodua, Indramayu, 45272, Indonesia \\ ${ }^{2}$ Jurusan Pendidikan Matematika, Universitas Negeri Yogyakarta. \\ Jalan Colombo No. 1, Karangmalang, Yogyakarta 55281, Indonesia. \\ * Corresponding Author. E-mail: sawi_ijo22@yahoo.com \\ Received: 16 September 2018; Revised: 17 October 2018; Accepted: 21 December 2018
}

\begin{abstract}
Abstrak
Penelitian ini bertujuan untuk mendeskripsikan kemampuan matematis, yang terdiri atas kemampuan penalaran dan representasi matematis siswa SMP di Kabupaten Indramayu, Jawa Barat. Penelitian ini merupakan penelitian survei dengan pendekatan kuantitatif. Populasi dalam penelitian ini adalah seluruh siswa SMP kelas VIII di Kabupaten Indramayu tahun pelajaran 2016/2017. Sampel penelitian sebanyak 390 siswa. Teknik pengambilan sampel yang digunakan adalah stratified random sampling.Pengumpulan data dilakukan melalui teknik Tes. Teknik analisis data menggunakan statistika deskriptif melalui dua cara, yaitu estimasi titik dan estimasi interval rata-rata untuk menentukan kategori ketercapaian pada masing-masing kemampuan matematis siswa. Hasil penelitian menunjukkan bahwa kemampuan matematis siswa SMP di Kabupaten Indramayu berada pada kategori sedang. Secara lebih spesifik rata-rata skor pada kemampuan penalaran matematis siswa termasuk dalam kategori sedang. Begitu juga pada rata-rata skor kemampuan representasi matematis siswa berada pada kategori sedang.
\end{abstract}

Kata Kunci: kemampuan penalaran matematis, komunikasi matematis, representasi matematis

\section{Exploration ability of mathematical reasoning and representation of junior high school students}

\begin{abstract}
This study aimed to describe the mathematical ability, which consists of the ability of mathematical reasoning and representation in junior high school students in Indramayu, West Java Province, Indonesia. This research was using survey method with quantitative approach. The population in this study were all grade VIII students in both state and private junior high schools in Indramayu district in academic year of 2016/2017 and 390 students selected as sample research. The sampling technique was stratified random sampling. Data collected using test technique. Technique data analysis used descriptive statistics through two ways, namely estimation point and the average of interval estimation to determine the category of achievement in each of the students' mathematical abilities. The result showed that the mathematical ability of junior high school students in Indramayu district was in the medium category. More specifically the average score on students' mathematical reasoning abilities was included in the moderate category. Similarly, the average score of students' mathematical representation ability was in the medium category.
\end{abstract}

Keywords: mathematical reasoning, mathematical communication, mathematical representation

How to Cite: Absorin, A., \& Sugiman, S. (2018). Eksplorasi kemampuan penalaran dan representasi matematis siswa sekolah menengah pertama. Pythagoras: Jurnal Pendidikan Matematika, 13(2), 189-202. doi:https://doi.org/10.21831/pg.v13i2.21249

https://doi.org/10.21831/pg.v13i2.21249

\section{PENDAHULUAN}

Dunia pendidikan di negara Indonesia yang semakin berkembang tidak dapat dipisahkan dari derasnya pengaruh kemajuan global.
Kemajuan teknologi dan ilmu pengetahuan berkembang sangat cepat, hal tersebut yang menjadi tantangan untuk dunia pendidikan di negara Indonesia. Dunia pendidikan di masa 
yang akan datang mampu mendukung pembangunan, seperti yang dikemukakan Trianto (2009, p.1) bahwa pendidikan mampu mengembangkan potensi siswa. Kebijakan Pendidikan Nasional dalam menyongsong pasar global harus mampu meningkatkan kualitas pendidikan, secara akademik ataupun non-akademik. Dengan demikian upaya yang dapat meningkatkan kualitas dunia pendidikan di negara kita secara akademik salah satunya adalah mata pelajaran matematika.

Peran matematika dalam dunia pendidikan sangat penting dan esensial terhadap perkembangan ilmu pengetahuan. Matematika sebagai dasar seluruh cabang ilmu pengetahuan digunakan sebagai alat yang sangat penting di berbagai bidang di seluruh dunia. Peran matematika di atas sejalan dengan Peraturan Menteri Pendidikan dan Kebudayaan (Permendikbud) Nomor 58 Tahun 2014 mengenai kurikulum 2013 Sekolah Menengah Pertama (SMP)/Madrasah Tsanawiyah (MTs), bahwa mata pelajaran matematika perlu diberikan kepada semua peserta mulai dari sekolah dasar, untuk membekali peserta didik dengan kemampuan berpikir logis, analitis, sistematis, kritis, inovatif dan kreatif, serta kemampuan bekerjasama. Kemampuan-kemampuan tersebut dapat dikembangkan dalam pembelajaran matematika

Terkait dengan matematika Chambers (2013, p.7) mendefinisikan "mathematics is objective fact: a study of reason and logic, a system of rigour, purity and beauty, free from societal influence, self contained, and interconnected structure". Pendapat tersebut menjelaskan bahwa matematika adalah fakta objek, studi dari penalaran dan logika, sebuah sistem ketelitian, kemurnian dan keindahan; bebas dari pengaruh sosial; mandiri; dan struktur yang saling berkaitan. Senada dengan pendapat di atas, Van de Walle (2010, p.13) mengemukakan bahwa matematika merupakan ilmu pengetahuan tentang konsep dan proses yang memiliki pola keteraturan dan urutan yang logis, mengerjakan matematika merupakan kegiatan menemukan dan mengeksplorasi keteraturan dan urutan tersebut, kemudian memberi arti pada keteraturan dan urutan tersebut. Berdasarkan pendapat-pendapat tersebut disimpulkan bahwa setiap siswa harus memiliki kompetensi matematika sebagai salah satu standar untuk mendapatkan kemudahan berkecimpung di dunia kerja.

Pembelajaran matematika merupakan il$\mathrm{mu}$ dasar yang mempunyai fungsi penting bagi pertumbuhan teknologi dan ilmu pengetahuan, sehingga memungkinkan siswa terampil berpikir secara rasional. Hal di atas sejalan dengan Permendikbud Nomor 21 Tahun 2016 tentang standar isi yang menjelaskan bahwa pembelajaran matematika bertujuan agar peserta didik memiliki kemampuan sebagai berikut: (1) memahami konsep; (2) menggunakan penalaran; (3) memecahkan masalah; (4) mengkomunikasikan gagasan; (5) memiliki sikap menghargai kegunaan matematika. Lebih lanjut, pembelajaran matematika merupakan suatu upaya guna mengarahkan aktivitas siswa ke arah aktivitas belajar. Aktivitas intelektual siswa dalam belajar matematika yang perlu diperhatikan dapat diklasifikasikan sebagai berikut: mengungkapkan, mentransformasikan, membuktikan, mengaplikasikan, menyelesaikan masalah, dan mengkomunikasikan. Dengan demikian, melalui proses pembelajaran matematika di sekolah, diharapkan dapat mengembangkan kemampuan siswa dalam berpikir logis, sistematis, kreatif dan bijaksana dalam memandang dan menyelesaikan masalah (Wardhani \& Rumiati, 2011, p.58)

Penilaian keberhasilan pembelajaran matematika, dan sains suatu negara sangat diperlukan dalam rangka sebagai tolak ukur kualitas pendidikan. Terkait penilaian keberhasilan pendidikan berstandar nasional di atas adalah hasil Ujian Nasional (UN). Permendikbud Nomor 66 Tahun 2013 bahwa UN merupakan kegiatan pengukuran kompetensi tertentu yang dicapai peserta didik dalam rangka menilai pencapaian kriteria minimal tentang sistem pendidikan yang termuat dalam Standar Nasional Pendidikan yang dilaksanakan secara nasional. Berdasarkan hasil rata-rata UN siswa SMP tahun pelajaran 2015-2016 mengalami penurunan, jika dibandingkan dengan tahun-tahun sebelumnya yang selalu mengalami peningkatan. Begitu pula dengan kondisi hasil rata-rata UN matematika SMP/MTs di Provinsi Jawa Barat terutama di Kabupaten Indramayu, yang tidak jauh berbeda mengalami penurunan dibandingkan dengan tahun-tahun pelajaran sebelumnya yang selalu mengalami peningkatan.

Penurunan hasil UN tersebut sudah dirasakan sebagai masalah yang cukup serius dalam pembelajaran matematika di sekolah. Lebih lanjut, penurunan hasil UN ini disebabkan karena belum berkembang secara maksimal kemampuan-kemampuan matematis siswa SMP dalam memahami dan menjawab soal-soal matematika. Dengan demikian peran pemerintah dengan melakukan perbaikan demi perbaikan 
Pythagoras, 12 (2), 2018 - 191

Absorin Absorin, Sugiman Sugiman

kurikulum sekolah sangat tepat yang bertujuan agar siswa memiliki kemampuan-kemampuan matematis. Ringkasan nilai rata-rata UN SMP/ MTs tahun 2015 dan 2016 disajikan Tabel 1.

Tabel 1. Nilai Rata-Rata UN SMP/MTS di Tingkat Nasional, dan di Kabupaten Indramayu 2014/ 2015 dan 2015/2016

\begin{tabular}{lcccc}
\hline Mata Pelajaran & \multicolumn{2}{c}{$\begin{array}{c}\text { SMP/MTs } \\
\text { Tingkat Nasional }\end{array}$} & \multicolumn{2}{c}{$\begin{array}{c}\text { SMP/MTs } \\
\text { Tingkat Kab. } \\
\text { Indramayu }\end{array}$} \\
\hline Bahasa Indonesia & 2015 & 2016 & 2015 & 2016 \\
Bahasa Inggris & 60,06 & 70,75 & 64,02 & 64,85 \\
Matematika & 56,28 & 50,24 & 51,29 & 45,40 \\
IPA & 59,88 & 56,27 & 53,46 & 36,86 \\
\hline
\end{tabular}

Berdasarkan data Tabel 1, dapat disimpulkan bahwa rata-rata nilai UN SMP/ MTs mata pelajaran matematika secara keseluruhan di Indonesia pada tahun 2016 yaitu 50,24 mengalami penurunan jika dibandingkan rerata UN tahun-tahun sebelumnya, serta pada tahun 2016 pula nilai UN matematika masih di bawah ratarata nilai UN mata pelajaran lainnya. Kondisi tersebut tidak jauh berbeda dengan prestasi UN matematika SMP/MTs di Provinsi Jawa Barat terutama di Kabupaten Indramayu. Terlihat dari nilai rerata UN matematika pada tahun 2016 yakni, 36,86 masih lebih rendah lagi jika dibandingkan dengan nilai rerata UN matematika tingkat nasional maupun tingkat Provinsi Jawa Barat.

Terkait penilaian keberhasilan berstandar nasional yaitu hasil UN tersebut, ada pula penilaian pendidikan berstandar Internasional yakni The Trends in International Mathematichs and Science Study (TIMSS) dan Programme for International Student Assessment (PISA). Data dari hasil TIMSS dan PISA siswa Indonesia adalah salah satu alasan yang melatarbelakangi perbaikan Kurikulum 2013. Lebih lanjut disebabkan karena siswa perwakilan dari negara Indonesia masih sering mengalami kesulitan menjawab materi ujian matematika berstandar Internasional tersebut yang berisi soal-soal non rutin. Ringkasan rata-rata persentase menjawab benar soal TIMSS 2011 disajikan pada Tabel 2.

Tabel 2. Rata-rata Persentase Menjawab Benar Soal TIMSS 2011

\begin{tabular}{cccc}
\hline Negara & Knowing & Applying & Reasoning \\
\hline Indonesia & $31(0,7)$ & $23(0,6)$ & $17(0,4)$ \\
Rata-rata & $49(0,1)$ & $39(0,1)$ & $30(0,1)$ \\
International & & & \\
\hline
\end{tabular}

(Mullis, Martin, Foy, \& Arora, 2012, p.462)
Tabel 2 menunjukkan kemampuan ratarata siswa dari negara Indonesia pada tiap domain masih jauh di bawah rata-rata International. Rata-rata persentase yang paling rendah adalah pada domain kognitif level penalaran (reasoning) yaitu 17\% dengan simpangan baku 0,4 yang menjawab secara benar dari rata-rata international sebanyak $30 \%$. Lebih lanjut, hasil PISA untuk kelas VIII juga menunjukkan bahwa literasi matematika di Indonesia masih rendah. Literasi matematika di sini didefinisikan sebagai kapasitas siswa untuk menganalisis, menalar, dan mengkomuni-kasikan matematika.

Data hasil PISA periode 2012 menempatkan Indonesia pada peringkat 64 dari 65 negara. Lebih lanjut, data hasil PISA terakhir yaitu tahun 2015 Indonesia berada pada peringkat 66 dari 72 negara peserta. Rata-rata nilai PISA Indonesia adalah 375 masih di bawah rata-rata internasional yaitu 494. Terkait hasil data dari TIMSS dan PISA di atas bertolakbelakang dengan pencapaian hasil siswa Indonesia dalam beberapa event matematika berskala Internasional lainnya, seperti International Mathematics Olimpiade (IMO). Lebih lanjut, dalam olimpiade matematika dunia Internasional seperti IMO tersebut, siswa Indonesia mulai jenjang Sekolah Dasar sampai Sekolah Menengah, memperoleh pencapaian hasil yang bagus dan membanggakan dengan menjuarai ajang bergengsi adu keterampilan menyelesaikan soal-soal matematika di olimpiade International matematika seperti IMO tersebut.

Sebagai bukti pada IMO tahun 2013 di Colombia tim olimpiade matematika lndonesia meraih 1 medali emas, 1 medali perak, dan 4 medali perunggu. Pada IMO 2013 tersebut tim olimpiade Indonesia menempati peringkat 19 dari 97 negara peserta. Kemudian pada IMO tahun 2014 tim olimpiade matematika Indonesia menempati peringkat 29 dari 101 negara peserta dengan memperoleh 2 medali perak, 3 medali perunggu, dan 1 penghargaan honorable mention (Dolinar, 2014, p.1). Lebih lanjut, pada IMO tahun 2015 tim olimpiade Indonesia mendapatkan peringkat 29 dari 104 negara peserta. Padahal dalam PISA dan TIMSS banyaknya negara peserta hanya sedikit, sedangkan eventevent olimpiade matematika berstandar International bergengsi lainnya seperti pada IMO jumlah negara peserta jauh lebih banyak. Berdasarkan uraian tersebut, muncul pertanyaan bagaimana kemampuan matematis siswa-siswa Indonesia yang sebenarnya, khususnya siswa-siswa di Kabupaten Indramayu dalam menjawab soal- 
soal setara PISA dan TIMSS. Lebih lanjut, kemampuan matematis tersebut mencakup kemampuan penalaran dan representasi matematis siswa di Kabupaten Indramayu.

Prestasi matematika dalam PISA dan TIMSS secara nasional sudah diketahui, akan tetapi belum terdapat pemetaan kemampuan matematis siswa SMP untuk masing-masing wilayah atau provinsi di Indonesia. Pemilihan Kabupaten Indramayu sebagai tempat penelitian, dikarenakan belum ada penelitian yang serupa yang menggali lebih dalam tentang kemampuan matematis siswa yang mencakup kemampuan penalaran dan representasi matematis siswa SMP di Kabupaten Indramayu. Lebih lanjut, kemampuan penalaran dan representasi matematis dipilih sebagai variabel penelitian, karena kedua kemampuan matematis siswa tersebut ada dalam pengukuran atau penilaian pendidikan berstandar international seperti PISA dan TIMSS. Kedua kemampuan matematis siswa di atas juga termasuk dalam lima standar proses pada pembelajaran matematika menurut Nasional Council of Teacher of Mathematics (NCTM, 2000, p.7), yaitu: problem solving (pemecahan masalah), reasoning and proof (penalaran dan bukti), communication (komunikasi), connection (hubungan), dan representation (penyajian).

Pemilihan sampel siswa kelas VIII SMP untuk menyelesaikan soal-soal tes yang mengukur kemampuan matematis yang mencakup kemampuan penalaran dan representasi matematis siswa menyesuaikan dari penilaian TIMSS. Berkaitan dengan hal tersebut, Piaget (Slavin, 2006, p.39) siswa usia lebih dari 11 tahun sudah berada pada tahap peralihan dari operasi konkrit ke operasi formal yang mencakup berpikir simbolik, abstrak, dan logis sehingga sesuai dengan karakteristik soal PISA dan TIMSS yang mencakup soal level pengetahuan hingga penalaran serta penggunaan konteks dalam soal PISA. Selain itu juga UN mulai tahun pelajaran 2015/ 2016 sampai UN tahun 2016/2017 sudah memuat soal-soal setara PISA. Sehingga pengembangan soal model PISA yang mengukur kemampuan siswa untuk menganalisis, menalar, dan merepresentasikan masalah matematika diperlukan dalam dunia pendidikan.

Kurikulum yang ada di Indonesia khususnya dalam belajar matematika, mengharuskan setiap siswa mampu mengembangkan kemampuan bernalar yang tercermin melalui kemampuan berpikir logis, kritis, sistematis, dan memiliki sifat objektif, jujur serta disiplin dalam pemecahan suatu masalah matematika. Kemam- puan penalaran matematis merupakan salah satu dari lima kemampuan yang penting diperlukan dan dikembangkan dalam pembelajaran matematika. Hal di atas sejalan dengan pendapat Brodie (2010, p.11) menyatakan "reasoning is a key element of mathematics and thus is central to learning mathematics in school". Pendapat di atas berarti bahwa penalaran matematis merupakan elemen kunci dari matematika dan sebagai pusat pembelajaran matematika di sekolah. Hal senada juga dijelaskan NCTM (2000, p.262) yang mengungkapkan bahwa penalaran merupakan bagian yang tak terpisahkan dari matematika. Siswa pada tingkat sekolah menengah harus berpandangan bahwa matematika itu melibatkan kegiatan memeriksa pola dan keteraturan, membuat dugaan tentang kemungkinan generalisasi dan mengevaluasi dugaan, membangun dan membuat argumen matematis. Pengalaman belajar siswa akan membantu dalam meningkatkan kemampuannya dalam menganalisis masalah-masalah matematika. Hal ini berarti bahwa pada siswa sekolah menengah, harusnya memiliki kemampuan penalaran yang baik dalam mempelajari matematika.

Kemampuan penalaran merupakan salah satu cabang dari matematika yang melibatkan logika, karena materi matematika dan penalaran matematis merupakan dua hal yang tidak dapat dipisahkan, yakni materi matematika dipahami melalui penalaran dan penalaran dipahami dan dilatihkan melalui belajar matematika. Hal di atas seperti yang diungkapkan Maarif (2016, p.115) menjelaskan bahwa "reasoning and mathematics are two aspects that cannot be separated as understood through mathematical reasoning”. Kutipan di atas mempunyai maksud bahwa penalaran dan matematika adalah dua aspek yang tidak dapat dipisahkan karena melalui penalaran matematika dapat dipahami.

Terkait dengan pengertian kemampuan penalaran matematis Clements dan Sarama (2009, p.203) menyatakan "logic (reasoning) is a branch of mathematics, and thinking involves logic at some point". Maksudnya bahwa kemampuan penalaran adalah cabang ilmu matematika melalui proses cara berpikir yang melibatkan logika dari suatu kesimpulan. Hal tersebut sesuai dengan pendapat Moshman (2015, p.22) menyatakan bahwa "reasoning is thinking aimed at reaching true or justifiable conclusions". Pendapat tersebut berarti bahwa penalaran merupakan proses berpikir yang bertujuan untuk mencapai kebenaran atau kesimpulan yang benar. 
Pythagoras, 12 (2), 2018 - 193

Absorin Absorin, Sugiman Sugiman

Lebih lanjut, Kurtz, et al (Goldstein, 2011, p.360) memberikan definisi yang lebih lengkap yaitu "reasoning is the cognitive processes by which people start with information and come to conclusions that go beyond that information". Hal tersebut bermakna penalaran adalah proses kognitif seseorang yang memulainya dengan informasi menuju pada penarikan suatu kesimpulan atas informasi tersebut. Berdasarkan penjelasan para ahli terkait penalaran matematis, disimpulkan bahwa kemampuan penalaran matematis adalah kemampuan siswa untuk dapat menyelesaikan permasalahan matematika secara logis dalam menemukan pola, menggeneralisasi dari pola, merumuskan dugaan serta melakukan penarikan kesimpulan yang logis dari suatu pernyataan. Dengan demikian, dapat diketahui bahwa kemampuan penalaran matematis tidak terlepas dari pengetahuan siswa yang telah dimiliki sebelumnya untuk kemudian digunakan dalam membantu menemukan suatu pengetahuan yang baru.

Lebih lanjut Brodie (2010, p.11) mengungkapkan bahwa intuisi, kreativitas, imajinasi, penjelasan dan komunikasi mempunyai peranan penting dalam penalaran matematis. Sejalan dengan pendapat tersebut Schwanke (2008, p.1) "by using a reasoning and proof journal, students are able to demonstrate their understanding of mathematical concepts in words and numbers. Each student has the opportunity to explore and develop a conceptual understanding for each math objective". Maksud kutipan di atas adalah dengan menggunakan penalaran dan pembuktian karya ilmiah, siswa dapat menunjukkan pemahaman mereka tentang konsep-konsep matematika dalam kata dan angka. Kemampuan penalaran dapat menjadi keterampilan dasar yang diperlukan untuk memahami konsep dan mengkonstruksi pengetahuan matematika. Setiap siswa memiliki kesempatan untuk mengeksplorasi dan mengembangkan pemahaman konseptual untuk setiap tujuan matematika. Kemampuan penalaran yang dimiliki oleh siswa pada saat menyelesaikan permasalahan matematika dapat menjadi salah satu sarana siswa untuk dapat melatih dengan baik kemampuan bernalarnya. Seperti yang diungkapkan oleh Bieda, Ji, Drweneke, Picard (2013, pp.1-2), bahwa setiap praktek-praktek memerlukan penalaran matematika, yang merupakan proses memunculkan rasa dan memahami ide-ide matematika dan konsep yang melekat pada prosedur. Siswa menggunakan penalaran ketika mereka terlibat dalam argumentasi matematika, sebuah proses yang melibatkan membuat dan membenarkan pernyataan matematika. Hakekatnya dalam pembelajaran matematika di sekolah, idealnya seorang siswa harus mampu bernalar secara logis, kritis terlebih dahulu serta kemudian harus mampu pula mengembangkan aktivitas kreatif kemampuan matematis lainnya dalam memecahkan suatu masalah matematika dan juga mampu mengekpresikan ide-idenya dalam bentuk tulisan maupun lisan.

Selain kemampuan penalaran yang harus dikembangkan oleh setiap siswa dalam pembelajaran matematika. Kemampuan yang tak kalah penting lainnya yang harus dimiliki setiap siswa dalam mempelajari matematika adalah kemampuan representasi matematis, sesuai lima standar proses pada pembelajaran matematika menurut NCTM. Kemampuan Berkaitan dengan pentingnya siswa memiliki kemampuan representasi matematis, Vergnaud (English, 2002, p.207) menyatakan bahwa representasi merupakan elemen penting dalam teori belajar dan mengajar matematika, bukan hanya karena penggunaan sistem simbol, sintaks dan semantik yang kaya, bervariasi, dan umum, tetapi ada dua alasan yang kuat, yaitu (1) matematika memerankan bagian esensial dalam membentuk konsep dunia nyata dan (2) matematika menjadikan penggunaan homomorpisme yang luas dalam mereduksi struktur ke struktur lainnya yang esensial. Sejalan dengan pernyataan tersebut, NCTM (2000, p.67) juga menyatakan bahwa representasi harus diperlakukan sebagai elemen penting dalam mendukung pemahaman siswa tentang konsep-konsep matematika dan hubungannya, dalam pendekatan berkomunikasi matematika, argumen, dan pemahaman untuk diri sendiri dan lainnya, dalam mengenali hubungan antara konsep-konsep matematika yang terkait, dan dalam menerapkan matematika untuk situasi masalah yang realistis melalui pemodelan. Dengan demikian seorang siswa dalam merepresentasikan masalah perlu memiliki keterampilan mengartikulasikan masalah yang sama ke dalam bentuk berbeda dengan menafsirkan dan menghubungkan sesuai dengan pengetahun yang dimilikinya

Terkait pengertian kemampuan representasi matematis Beetlestone (Farhan \& Retnawati, 2014, p.229), menjelaskan bahwa representasi matematis merupakan kreativitas yang melibatkan pengungkapan atau pengekspresian gagasan dan perasaan serta penggunaan bebagai macam cara untuk melakukannya. Selanjutnya Sabirin (2014, p.33), mengemukakan bahwa 
representasi adalah bentuk interpretasi pemikiran siswa terhadap suatu masalah, yang digunakan sebagai alat bantu untuk menemukan solusi dari masalah tersebut. Berkaitan dengan pengertian representasi menurut Hwang, Chen, Dung, dan Yang (2007, p.192) mengemukakan bahwa dalam ilmu psikologi, representasi berarti permodelan hal-hal konkret dalam dunia nyata ke dalam konsep atau simbol abstrak.

Lebih lanjut, Goldin (Salkind, 2007, p.2) menyatakan bahwa representasi adalah sebuah konfigurasi atau wujud yang dapat menyajikan sesuatu yang lain dalam beberapa cara. Berdasarkan pendapat para ahli, disimpulkan bahwa kemampuan representasi matematis ialah kemampuan siswa untuk memodelkan hal-hal yang konkret dalam dunia nyata ke dalam konsep atau simbol abstrak sehingga dapat menggambarkan atau melambangkan suatu cara dalam mencari solusi dari masalah yang sedang dihadapinya. Kemudian untuk Indikator dari representasi matematis yakni, dapat menerjemahkan masalah matematika kedalam bentuk representasi (1) gambar; (2) simbol aritmetika; dan (3) tabel.

Kemampuan representasi matematis sangat membantu siswa membangun persamaan matematika yang benar dalam memecahkan masalah matematika. Hal lain mengenai representasi matematis dikemukakan Kalathil dan Sherin (2000, p.27), menyatakan bahwa representasi dapat dianggap sebagai eksternalisasi model mental siswa yang dapat dimanipulasi, dan digunakan sebagai informasi bersama. Lebih lanjut, Dufresne, Gerace dan Leonard (2004, p.2) dalam penelitiannya mengemukakan bahwa ketika membaca dan menganalisis masalah, salah satu bentuk representasi masalah yakni dengan menafsirkan dan menghubungkan dengan pengetahuan yang dimilikinya. Pengetahuan yang digunakan untuk merepresentasikan suatu masalah sangat bervarisi, yang dapat mencakup pengetahuan tentang konsep dan prinsipprinsip, persamaan, prosedur dan masalah-masalah yang terkait. Kemampuan representasi matematis yang dimunculkan oleh siswa merupakan ungkapan-ungkapan dari gagasan-gagasan atau ide-ide matematika yang ditampilkan siswa dalam upayanya untuk mencari suatu solusi dari masalah yang sedang dihadapinya. Hwang, et al (2007, p.191) dalam penelitiannya mengemukakan bahwa bahwa memecahkan masalah aplikasi matematika, siswa perlu mengamati dan mencari tahu pola atau aturan khusus dalam masalah. Pendapat tersebut artinya siswa perlu merumuskan masalah aplikasi nyata ke dalam masalah matematika abstrak. Kemudian dalam proses perumusan, siswa harus memiliki beberapa keterampilan representasi untuk mengartikulasikan masalah yang sama dalam bentuk yang berbeda. Selanjutnya NCTM (2000, p.68) menyatakan bahwa representasi dapat membantu siswa dalam mengatur pikiran mereka. Siswa yang menggunakan representasi dapat membantu menjadikan ide-ide matematika lebih konkrit dan tersedia untuk refleksi.

Selain itu, Kennedy, Tipps, dan Johnson (2008, p.50), tahap pertama dari representasi adalah enaktif yang menunjukkan peran benda fisik dalam belajar. Tahap kedua adalah ikonik yang mengacu pada grafik dan gambar. Tahap ketiga adalah simbolik yang menggunakan katakata, angka-angka, dan simbol lain untuk mewakili ide, benda, dan aksi. Goldin (2001, p.1-2) menyatakan bahwa sistem representasi penting untuk matematika dan pembelajaran yang memiliki struktur, sehingga representasi yang berbeda dalam sebuah sistem yang kaya terkait satu sama lain. Sejalan dengan pendapat di atas, Caprioara (2014, p.1860) mengungkapkan bahwa dalam matematika sebuah situasi masalah merupakan situasi belajar dimana guru membayangkan untuk menciptakan ruang untuk refleksi dan analisis sekitar masalah atau pertanyaan untuk dipecahkan. Situasi ini harus memungkinkan siswa untuk meningkatkan pengetahuan, melalui representasi baru. Hal senada dikemukakan Dauglaa (Brumbaugh, Moch \& Wilkinson, 2005, p.229) yang menyatakan bahwa istilah representasi menganggap antara proses dan hasil, dengan kata lain mengarah pada tindakan menyerap konsep atau hubungan matematis dalam beberapa bentuk dan pembentukan dirinya sendiri.

Lebih lanjut NCTM (2000, p.67), menetapkan pogram representasi pembelajaran dari pra-taman kanak-kanak sampai kelas 12 harus memungkinkan siswa untuk: (1) Menciptakan dan menggunakan representasi untuk mengorganisir, mencatat, dan mengomunikasikan ideide matematis; (2) Memilih, menerapkan, dan menerjemahkan representasi matematis unituk memecahkan masalah; (3) Menggunakan representasi untuk memodelkan dan menginterpretasikan fenomena fisik, sosial, dan fenomena matematis. Selain itu, menurut Goldin dan Kaput (1996, p.399) representasi di bagi menjadi dua bagian yaitu representasi eksternal dan representasi internal. Representasi eksternal adalah suatu pengungkapan ide matematika menggunakan simbol dan gambar yang tertulis dan 
Pythagoras, 12 (2), 2018 - 195

Absorin Absorin, Sugiman Sugiman

bahasa verbal, sedangkan representasi internal disebut juga sebagai representasi mental antara lain: simbol personal siswa (student personal symbols), bahasa alami siswa (student natural language), gambar visual (visual imagery), representasi spasial (spatial representation), dan strategi penyelesaian masalah dan heuristik penyelesaian masalah (problem solving strategies and heuristik).

Goldin dan Shteingold (Panasuk, 2010, p.237) menyatakan bahwa pertama dan paling utama dalam representasi adalah representasi sistem eksternal dan representasi sistem internal dan interaksi diantaranya adalah penting untuk belajar dan mengajar matematika. Representasi sistem eksternal meliputi representasi konvensional yang biasanya berupa simbol, sedangkan representasi sistem internal diciptakan didalam pikiran seseorang dan digunakan untuk menunjukkan makna matematis. Sistem numerasi, persamaan matematika, ungkapan aljabar, grafik, gambar geometri, dan garis bilangan merupakan contoh dari representasi eksternal. Representasi eksternal juga meliputi bahasa yang ditulis dan diucapkan, contoh dari representasi internal meliputi sistem notasi perseorangan, bahasa asli, perumpamaan visual, dan strategi pemecahan masalah (Salkind, 2007, p.4).

Lesh, Post, dan Behr (Hwang, et al, 2007, p.192) membagi representasi yang digunakan dalam pendidikan matematika kedalam lima jenis, meliputi representasi objek dunia nyata, representasi konkret, representasi simbol aritmatika, representasi bahasa lisan atau verbal dan representasi gambar atau grafik. Cai, Jakabcsin, \& Lane (1996, p.244) menyatakan bahwa ragam representasi yang sering digunakan dalam mengkomunikasikan matematika antara lain: tabel, grafik, gambar, pernyataan matematika, teka tertulis, atau kombinasi dari semuanya.

Berdasarkan kedua kemampuan matematis, yakni kemampuan penalaran dan representasi matematis merupakan kemampuan yang harus dimiliki siswa dalam pembelajaran matematika di sekolah, dimana kedua kemampuan matematis tersebut saling terikat satu sama lain dalam menyelesaikan sosl-soal matematika, seperti yang dikemukakan NCTM (2000, p.67), bahwa kemampuan matematis yang dituntut pada pembelajaran matematika adalah kemampuan penyelesaian masalah, kemampuan penalaran, dan kemampuan untuk merepresentasikan ide matematis. Lebih lanjut, seorang siswa dengan kemampuan penalarannya dapat membantu siswa lain untuk membangun suatu kon- sep pemahaman baru, dengan cara mengkomunikasikan atau mengekspresikan ide-ide/ gagasan baik secara lisan maupun tulisan dan juga merepresentasikannya kedalam bentuk gambar, grafik, simbol aritmetika, tabel dan lain sebagainya dalam rangka menyelesaikan berbagai permasalahan, khususnya pada saat menyelesaikan masalah matematika.

Proses pembelajaran matematika siswa dalam bernalar, dan berkomunikasi matematis akan digunakan representasi-representasi dalam menggambarkan ide-ide matematika yang disampaikan. Oleh karena itu dalam kemampuan bernalar, berkomunikasi matematis terdapat kemampuan representasi matematis didalamnya. Suatu masalah yang rumit akan menjadi sederhana jika menggunakan kemampuan matematis yang tepat sesuai dengan permasalahan tersebut. Kemampuan penalaran dan representasi matematis yang dimunculkan siswa dalam menyelesaikan soal-soal matematika, merupakan ungkapan-ungkapan dari ide-ide atau gagasangagasan matematis yang dimunculkan siswa dalam upaya untuk mencari suatu solusi dari masalah yang sedang dihadapinya.

Kurikulum yang ada di Indonesia khususnya dalam belajar matematika, mengharuskan setiap siswa mampu memperoleh kemampuan matematis diantaranya kemampuan bernalar dan merepresentasikannya dengan baik, yang tercermin melalui kemampuan berpikir logis, kritis, sistematis dan memiliki sifat objektif, jujur serta disiplin dalam pemecahan suatu masalah matematika. Berbagai kemampuan matematis dan keterampilan siswa dalam pembelajaran matematika, pada setiap satuan pendidikan diharapkan mampu membekali siswa dalam menghadapi berbagai permasalahan matematika dalam kehidupan sehari-hari dan dalam mempelajari berbagai ilmu pengetahuan di bidang lain. Pembelajaran matematika di sekolah bertujuan mengembangkan potensi siswa agar mampu memahami matematika dengan benar. Dengan demikian berarti kedua kemampuan matematis tersebut wajib dimiliki siswa dan dilatih secara terus menerus, dengan harapan siswa lebih aktif dan kreatif menyelesaikan permasalahan matematika dengan baik dan benar, serta dapat meningkatkan keberhasilan penilaian pendidikan di kanca nasional melalui UN maupun International seperti PISA dan TIMSS.

Berdasarkan latar belakang masalah berikut kajian teori yang telah dikemukakan sebelumnya, maka penelitian ini bertujuan untuk mendeskripsikan kemampuan matematis, yang 
terdiri atas kemampuan penalaran dan representasi matematis siswa SMP di Kabupaten Indramayu, Jawa Barat. Dengan adanya penelitian ini, hasilnya diharapkan dapat dijadikan masukan bagi pemangku kebijakan untuk perbaikan kualitas pendidikan di Kabupaten Indramayu khususnya, dan Indonesia umumnya.

\section{METODE}

Jenis penelitian ini adalah penelitian dengan menggunakan metode survei dengan pendekatan kuantitatif. Tempat penelitian ini dilaksanakan di seluruh SMP baik negeri maupun swasta di Kabupaten Indramayu yang telah ditetapkan sebagai sampel. Subjek penelitian ini adalah siswa kelas VIII SMP di Kabupaten Indramayu. Sementara itu, teknik pengambilan sampel yang digunakan adalah stratified random sampling (teknik sampling bertingkat).

Teknik pengumpulan data yang digunakan dalam penelitian ini adalah tes. Pengumpulan data tes dilakukan dengan cara memberikan soal tes matematika yang mengukur kemampuan matematis yang mencakup kemampuan penalaran dan representasi matematis kepada siswa secara tertulis. Siswa diminta untuk menjawab soal beserta langkah penyelesaian masalah. Setelah itu, lembar jawab siswa dikumpulkan dan direkap. Selanjutnya, dilakukan analisis pada lembar jawab siswa dalam menyelesaikan soal tes tersebut serta penilaian lembar jawab siswa sesuai dengan pedoman penskoran yang telah ditetapkan.

Soal tes matematika yang mengukur kemampuan matematis siswa diujikan sebanyak 8 soal tes uraian. Soal tes uraian tersebut terdiri dari 6 butir soal yang berkaitan dengan materi pokok matematika, yaitu bilangan, aljabar dan geometri yang dipelajari di kelas VII. Kemudian terdapat 4 soal materi pokok aljabar dan statistika yang dipelajari di kelas VIII. Setiap siswa yang menjadi sampel penelitian mengerjakan 15 item pertanyaan dari 8 soal tes uraian dengan rincian 9 item pertanyaan yang mengukur kemampuan penalaran matematis, dan 6 item pertanyaan yang mengukur kemampuan representasi matematis.

Data dalam penelitian ini berupa skor kemampuan matematis siswa SMP di Kabupaten Indramayu yang mencakup kemampuan penalaran dan representasi matematis. Setelah itu, kategorisasi kemampuan matematis siswa dilakukan melalui suatu estimasi atau taksiran untuk rata-rata populasi. Estimasi yang dilakukan terhadap rata-rata populasi terdiri dari dua jenis yaitu estimasi titik dan estimasi interval. Estimasi titik menggunakan nilai rata-rata sampel sedangkan estimasi interval menggunkan rumus $t$ berikut.

$$
\mu=\bar{x} \pm t_{a / 2} \frac{s}{\sqrt{n}}
$$

Keterangan:

$\mu \quad$ : Rata-rata populasi

$\bar{x} \quad$ : Rata-rata sampel

$t_{a / 2}:$ Nilai $t$ dengan derajat bebas $(n-1)$

$n \quad$ : Ukuran sampel

$s \quad$ : Standar deviasi sampel

(Anderson, Sweeney \& Williams, 2010, p. 315).

Tahap selanjutnya adalah memberikan justifikasi terhadap estimasi titik dan estimasi interval untuk mengetahui kategori ketercapaian kemampuan penalaran dan representasi matematis siswa pada Tabel 1.

Tabel 1. Kategori Skor Kemampuan Matematis

\begin{tabular}{cc}
\hline Kategori & Interval Skor \\
\hline Sangat Tinggi & $75<\mathrm{X} \leq 100$ \\
Tinggi & $58,33<\mathrm{X} \leq 75$ \\
Sedang & $41,67<\mathrm{X} \leq 58,33$ \\
Rendah & $25<\mathrm{X} \leq 41,67$ \\
Sangat Rendah & $0<\mathrm{X} \leq 25$ \\
\hline
\end{tabular}

(Ebel \& Frisbie, 1991, p.280)

\section{HASIL DAN PEMBAHASAN}

\section{Deskripsi Hasil}

Deskripsi data hasil tes kemampuan matematis siswa sampel kelas VIII di 15 SMP di Kabupaten Indramayu dapat dilihat Tabel 2.

Tabel 2. Estimasi Titik Rata-rata Skor Kemampuan Matematis

\begin{tabular}{lcccc}
\hline Kemampuan & SMP di & \multicolumn{3}{c}{ Strata Sekolah } \\
\cline { 3 - 5 } Matematis & Indramayu & Tinggi & Sedang & Rendah \\
\hline Penalaran & 47,3 & 52 & 49,3 & 40,7 \\
Representasi & 57,04 & 62,72 & 56,96 & 51,44 \\
\hline
\end{tabular}

Berdasarkan Tabel 2, dapat dilihat bahwa rata-rata kemampuan representasi lebih tinggi dibandingkan rata-rata kemampuan penalaran dan komunikasi. Ditinjau dari strata sekolah sampel yang digunakan, sekolah yang termasuk dalam kategori strata rendah, rata-rata kemampuan matematisnya paling rendah dibandingkan rata-rata kemampuan matematis sekolah strata sedang dan tinggi. Hal ini menunjukkan bahwa strata sekolah berpengaruh terhadap kemampuan matematis siswa yang ditinjau dari kemampuan penalaran dan representasi. 
Jika rata-rata pada Tabel 2 dikategorisasi, maka kategori dari masing-masing kemampuan matematis disajikan pada Tabel 3.

Tabel 3. Kategorisasi Kemampuan Matematis

\begin{tabular}{lcccc}
\hline Kemampuan & SMP di & \multicolumn{3}{c}{ Strata Sekolah } \\
\cline { 3 - 5 } Matematis & Indramayu & Tinggi & Sedang & Rendah \\
\hline Penalaran & Sedang & Sedang & Sedang & Rendah \\
Representasi & Sedang & Tinggi & Sedang & Sedang \\
\hline
\end{tabular}

Berdasarkan Tabel 3, secara umum kemampuan matematis siswa berada pada kategori sedang. Namun jika dilihat dari strata sekolahnya, sekolah dengan strata tinggi memiliki kemampuan representasi pada kategori tinggi.

Deskripsi Kemampuan Penalaran Matematis

Selanjutnya deskripsi kemampuan penalaran matematis siswa ditinjau dari indikatornya disajikan pada Tabel 4.

Tabel 4. Estimasi Titik Rata-rata Skor Kemampuan Penalaran Matematis

\begin{tabular}{lccc}
\hline \multirow{2}{*}{ Indikator } & \multicolumn{3}{c}{ Strata Sekolah } \\
\cline { 2 - 4 } & Tinggi & Sedang & Rendah \\
\hline $\begin{array}{l}\text { Menemukan pola pada suatu } \\
\text { gejala matematis }\end{array}$ & 42,5 & 41,06 & 34,62 \\
$\begin{array}{l}\text { Merumuskan suatu dugaan } \\
\text { matematis }\end{array}$ & 63,3 & 58,1 & 49,9 \\
$\begin{array}{l}\text { Menarik kesimpulan dari } \\
\text { pernyataan suatu argumen }\end{array}$ & 68,72 & 66,67 & 57,44 \\
Membuat generalisasi & 25,1 & 22,5 & 12,6 \\
\hline
\end{tabular}

Berdasarkan Tabel 4, terlihat bahwa capaian tertinggi siswa yaitu pada indikator menarik kesimpulan dari pernyataan suatu argumen, baik pada sekolah dengan strata tinggi, sedang, dan rendah. Adapun indikator yang dianggap paling sulit oleh siswa yaitu membuat generalisasi, baik pada sekolah strata tinggi, sedang, maupun rendah.

Selanjutnya, jika rata-rata pada Tabel 4 dikategorisasi, maka kategori kemampuan penalaran matematis siswa ditinjau dari indikatornya disajikan pada Tabel 5.

Tabel 5. Kategorisasi Kemampuan Penalaran Matematis Siswa

\begin{tabular}{lccc}
\hline \multicolumn{1}{c}{ Indikator } & $\begin{array}{c}\text { Sekolah } \\
\text { Tinggi }\end{array}$ & $\begin{array}{c}\text { Sekolah } \\
\text { Sedang }\end{array}$ & Sekolah \\
& Rendah \\
\hline $\begin{array}{l}\text { Menemukan pola pada suatu } \\
\text { gejala matematis }\end{array}$ & Sedang & Rendah & Rendah \\
$\begin{array}{l}\text { Merumuskan suatu dugaan } \\
\text { matematis }\end{array}$ & Tinggi & Sedang & Sedang \\
$\begin{array}{l}\text { Menarik kesimpulan dari } \\
\text { pernyataan suatu argumen } \\
\text { Membuat generalisasi }\end{array}$ & Tinggi & Tinggi & Sedang \\
& Rendah & Sangat & Sangat \\
& & Rendah & Rendah \\
\hline
\end{tabular}

Mengacu pada Tabel 5, kemampuan penalaran matematis siswa sekolah strata rendah dapat dikategorikan masih rendah, bahkan dari keempat indikator penalaran, tak satupun capaian sekolah strata rendah yang berada pada kategori tinggi.

Deskripsi Kemampuan Representasi Matematis

Deskripsi kemampuan representasi matematis siswa ditinjau dari indikatornya disajikan pada Tabel 6.

Tabel 6. Estimasi Titik Rata-rata Skor

Kemampuan Representasi Matematis

\begin{tabular}{lccc}
\hline \multirow{2}{*}{\multicolumn{1}{c}{ Indikator }} & \multicolumn{3}{c}{ Strata Sekolah } \\
\cline { 2 - 4 } & Tinggi & Sedang & Rendah \\
\hline Representasi Gambar & 49,62 & 45,48 & 40,48 \\
Representasi Simbol & 72,02 & 65,48 & 58,08 \\
Aritmetika & 66,54 & 59,9 & 55,77 \\
Representasi Tabel. &
\end{tabular}

Dari Tabel 6 dapat dilihat bahwa indikator representasi gambar merupakan indikator dengan rata-rata pencapaian terendah, baik pada sekolah dengan strata tinggi, sedang maupun rendah. Namun jika dibandingkan rata-rata antara strata, sekolah dengan strata tinggi memperoleh rata-rata paling tinggi untuk ketiga indikator kemampuan representasi, disusul kemudian sekolah dengan strata sedang.

Berikutnya jika rata-rata pada Tabel 6 dikategorisasi, maka kategori kemampuan representasi matematis siswa dapat dilihat Tabel 7.

Tabel 7. Kategorisasi Kemampuan Representasi Matematis Siswa

\begin{tabular}{lccc}
\hline \multicolumn{1}{c}{ Indikator } & $\begin{array}{c}\text { Sekolah } \\
\text { Tinggi }\end{array}$ & $\begin{array}{c}\text { Sekolah } \\
\text { Sedang }\end{array}$ & $\begin{array}{l}\text { Sekolah } \\
\text { Rendah }\end{array}$ \\
\hline Representasi Gambar & Sedang & Sedang & Rendah \\
Representasi Simbol & Tinggi & Tinggi & Sedang \\
Aritmetika & Tinggi & Tinggi & Sedang \\
Representasi Tabel & &
\end{tabular}

Berdasarkan Tabel 7, dapat dilihat bahwa kategori kemampuan representasi matematis siswa sekolah strata tinggi dan sedang adalah sama, namun untuk sekolah dengan strata rendah, rata-rata untuk ketiga indikator representasi belum ada yang mencapai kategori tinggi.

\section{Estimasi Interval Penalaran Matematis}

Interval kemampuan penalaran matematis siswa ditinjau dari indikatornya dapat dilihat pada Tabel 8. Berdasarkan Tabel 8, dapat dilihat bahwa untuk indikator pertama, kemampuan tertinggi siswa pada sekolah strata rendah hampir setara dengan kemampuan terendah siswa pada sekolah strata tinggi. Sedangkan untuk 
indikator kedua, kemampuan tertinggi siswa pada sekolah strata rendah tidak lebih baik dari kemampuan terendah siswa pada sekolah strata sedang dan tinggi. Hal yang sama juga berlaku untuk indikator ketiga dan keempat.

Tabel 8. Estimasi Interval Rata-rata Skor Kemampuan Panalaran Matematis

\begin{tabular}{|c|c|c|c|}
\hline \multirow{2}{*}{ Indikator } & \multicolumn{3}{|c|}{ Strata Sekolah } \\
\hline & Tinggi & Sedang & Rendah \\
\hline $\begin{array}{l}\text { Menemukan pola pada } \\
\text { suatu gejala matematis }\end{array}$ & $38,19-46,81$ & $36,65-45,46$ & $31,08-38,15$ \\
\hline $\begin{array}{l}\text { Merumuskan suatu } \\
\text { dugaan matematis }\end{array}$ & $59,41-67,12$ & $54,28-61,87$ & $46,56-53,25$ \\
\hline $\begin{array}{l}\text { Menarik kesimpulan } \\
\text { dari pernyataan suatu } \\
\text { argumen }\end{array}$ & $65,11-72,32$ & $62,91-70,43$ & $54,13-60,74$ \\
\hline Membuat generalisasi & $21,26-28,93$ & $19,23-25,77$ & $10,79-14,40$ \\
\hline
\end{tabular}

Estimasi Interval Representasi Matematis

Interval kemampuan representasi matematis siswa ditinjau dari indikatornya disajikan pada Tabel 9. Berdasarkan Tabel 9, dapat dilihat bahwa untuk indikator pertama, kemampuan tertinggi siswa pada sekolah strata rendah hampir setara dengan kemampuan terendah siswa pada sekolah strata sedang, namun masih di bawah kemampuan terendah siswa pada strata tinggi. Untuk indikator kedua, kemampuan tertinggi siswa pada sekolah strata rendah masih di bawah kemampuan siswa pada sekolah strata sedang dan tinggi. Namun untuk indikator ketiga, kemampuan tertinggi siswa pada sekolah strata rendah sudah di atas kemampuan terendah siswa pada sekolah strata sedang, tetapi masih di bawah kemampuan terendah siswa pada sekolah strata tinggi.

Tabel 9. Estimasi Interval Rata-rata Skor Kemampuan Representasi Matematis

\begin{tabular}{lc}
\hline \multicolumn{1}{c}{ Indikator } & \multicolumn{2}{c}{ Strata Sekolah } \\
\cline { 2 - 2 } & Tinggi Sedang Rendah \\
\hline $\begin{array}{l}\text { Representasi } \\
\text { Gambar }\end{array}$ & $45,54-53,6942,18-48,7837,99-42,97$ \\
\hline $\begin{array}{l}\text { Representasi Simbol } \\
\text { Aritmetika }\end{array}$ & $70,02-74,0263,29-67,6855,71-60,44$ \\
\hline Representasi Tabel. & $62,41-70,6655,83-63,9852,34-59,20$ \\
\hline
\end{tabular}

\section{Pembahasan}

\section{Kemampuan Penalaran Matematis Siswa}

Hasil analisis rata-rata skor jawaban siswa yang berasal dari strata sekolah tinggi memiliki capaian rata-rata skor yang lebih baik, jika dibandingkan strata sekolah sedang maupun rendah. Ditinjau dari masing-masing indikator kemampuan penalaran matematis, menunjukkan bahwa pada indikator menarik kesimpulan dari pernyataan suatu argumen menempati urutan terbaik dengan skor rata-rata tertinggi. Kemudian indikator kemampuan siswa membuat generalisasi merupakan capaian rata-rata skor terendah siswa. Berikut disajikan contoh soal kemampuan penalaran matematis siswa.

1. Pada tanggal 01 Desember 2015 ayah menabung sejumlah uang di suatu bank yang
menerapkan bunga tunggal perbulan. Pada awal bulan Januari tahun 2016 tabungan ayah
menjadi Rp. $10.050 .000,00$, sementara pada awal bulan Februari tahun 2017 tabungan
ayah menjadi Rp. $10.700 .000,00$.
A. Buatlah tabel untuk mengilustrasikan banyaknya uang ayah pada awal menabung
bulan Desember 2015 sampai dengan Juli 2016 .
B. Berapakah tabungan ayah pada awal bulan Desember tahun 2016?

\section{Gambar 1. Soal Penalaran Matematis}

Gambar 1 yakni soal nomor 1.B terkait dengan indikator kemampuan siswa menemukan pola pada suatu gejala matematis. Selanjutnya contoh respon jawaban siswa dalam menjawab soal pada Gambar 1 disajikan pada Gambar 2. Gambar 2 merupakan jawaban benar siswa, yang lengkap dan detail (full credit). Berdasarkan jawaban siswa di atas menunjukkan bahwa siswa mempunyai kemampuan bernalar yang sangat baik. Dibuktikan dengan jawaban siswa yang mampu memahami dan menangkap informasi yang diperoleh dari soal, sehingga dapat menyusun pola perhitungan jumlah tabungan dengan tepat, rinci, lengkap dan detail.

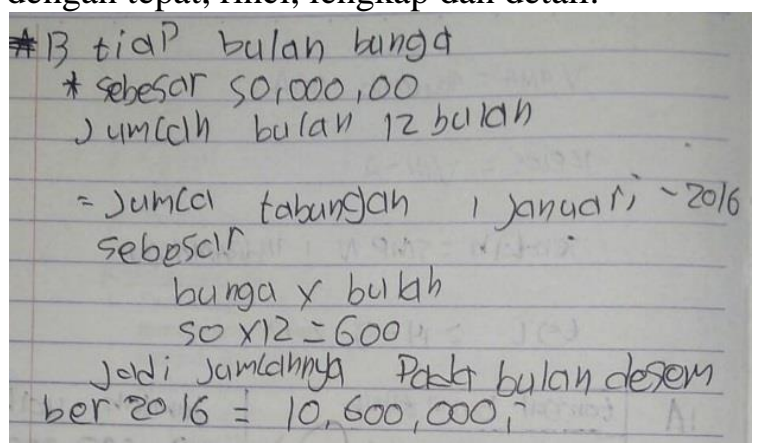

\section{Gambar 2. Contoh Jawaban Siswa Soal Penalaran Matematis}

Berdasarkan paparan data diskusi peniliti dengan siswa serta hasil jawaban siswa di atas, disimpulkan bahwa penalaran siswa dalam menyelesaikan soal kemampuan penalaran matematis nomor 1.B pada setiap tahapan sebagai berikut:

\section{Memahami Masalah}

Pada tahapan ini siswa melakukan penalaran: (1). Mengungkapkan bahwa masalah yang akan diselesaikan dalam menentukan jumlah tabungan ayah pada awal menabung sampai dengan bulan Desember 2016 sudah terbayangkan dengan menentukan terlebih dahulu pola bunga 
Pythagoras, 12 (2), 2018 - 199

Absorin Absorin, Sugiman Sugiman

tunggal setiap bulannya beserta langkah-langkah penyelesaiannya; (2). Siswa melakukan dugaan awal mengenai jumlah uang tabungan ayah pada saat menabung di bulan Desember tahun 2015.

\section{Merencanakan Penyelesaian}

Pada tahapan ini, siswa melakukan penalaran dengan membayangkan dan mencoba dugaan awal mengenai jumlah uang tabungan ayah pada saat awal menabung dan kemudian menambahkan dengan bunga tunggal setiap bulannya.

\section{Melakukan Rencana Penyelesaian}

Pada tahapan ini, siswa melakukan penalaran dengan melakukan perhitungan jumlah tabungan ayah pada awal menabung dengan pola bungan tunggal setiap bulannya berdasarkan informasi yang sudah diperoleh dari soal.

\section{Memeriksa Kembali}

Pada tahapan ini, siswa melakukan penalaran dengan memeriksa kembali jawaban yang sudah dikerjakan tanpa menggunakan catatan lain (coret-coretan) dan yakin dengan jawaban yang telah ditemukan. Lebih lanjut, dari hasil analisis jawaban siswa, persentase siswa menjawab benar dari 390 siswa sampel sebanyak 17\% atau sekitar 67 siswa SMP di Kabupaten Indramayu mampu menjawab dengan benar, dengan pola perhitungan lengkap dan detail (full credit). Pada soal tersebut banyak siswa yang berkemampuan matematis tinggi yang berasal dari strata sekolah tinggi lebih banyak menjawab benar (full credit). Jika dibandingkan siswa yang berasal dari strata sekolah sedang maupun renda. Siswa sampel yang menjawab benar tetapi pola perhitungan yang ditulis pada lembar jawaban kurang lengkap sebanyak 15\% atau 57 siswa. Kemudian untuk jawaban siswa yang mempunyai sedikit kesalahan atau jawaban siswa sebagian benar sebanyak $17 \%$ atau 66 siswa. Kemudian untuk persentase jawaban salah dengan pola perhitungan jawaban siswa yang salah pula sebesar 28\% atau sebanyak 110 siswa, serta untuk siswa yang tidak menjawab atau tidak menuliskan apapun pada lembar jawaban sekitar $23 \%$ atau sebanyak 90 siswa masih lemah dalam bernalar matematis. Hal ini disebabkan karena siswa belum menguasai materi yang dipelajari dan belum terbiasa menyelesaikan soal dalam menemukan pola, sehingga siswa mengalami kesulitan dalam menggambarkan atau memodelkan solusi penyelesaianya.
Gambar 3 merupakan contoh respon jawaban siswa dalam menyelesaikan soal mengukur kemampuan penalaran matematis untuk soal nomor 8.B.

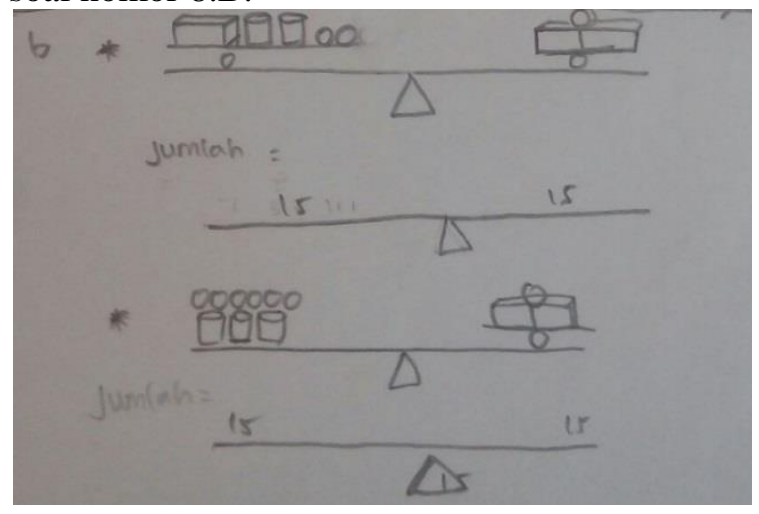

Gambar 33. Contoh Jawaban Siswa Soal Penalaran Matematis

Jawaban siswa pada Gambar 3, menunjukkan bahwa siswa mempunyai kemampuan bernalar yang sangat baik. Siswa tidak hanya mampu memahami dan menangkap informasi yang diperoleh dari soal, tetapi juga siswa mampu menyatakan ide-ide matematis yang diekspresikan kedalam bentuk gambar. Lebih lanjut, peneliti melakukan diskusi dengan siswa yang bertujuan mengeksplor kemampuan bernalar siswa sedalam-dalamnya yang disesuaikan dengan kondisi tulisan maupun penjelasan jawaban siswa di atas tersebut. Pertama, menurut siswa yang dilakukannya setelah mendapatkan informasi dari gambar timbangan 1 sampai 2 yang disajikan pada soal nomor 8.B, membuat perkiraan spontan berat 1 bola, 1 tabung dan 1 balok. Siswa dengan mencoret-coret pada lembar jawaban yang masih kosong, membuat dugaan dengan pemisalan jika berat 1 bola adalah $x$, 1 tabung adalah $3 x$, karena 1 tabung mempunyai keseimbangan sempurna dengan 3 bola, dan 1 balok adalah $7 x_{s}$ karena terdiri dari 2 tabung dan 1 bola sesuai gambar yang disajikan pada soal.

Setelah itu, berdasarkan informasi lanjutan dari gambar timbangan 3, siswa melihat pada gambar timbangan 3, ada 2 balok dan 1 bola. Lebih lanjut, Siswa melakukan dugaan dengan pemisalan bahwa berat 2 balok dan 1 bola adalah $(7 x+7 x+x)=15 x$. Kemudian langkah berikutnya menurut siswa, membuat analisis dugaan pada timbangan 3 yang terdiri dari 2 balok dan 1 bola agar seimbang sempurna. Siswa menyatakan ide matematisnya dengan mulai membuat ulang gambar timbangan 3 , dan selanjutnya membuat kemungkinan-kemungkinan berat 2 balok dan 1 bola, jika di setarakan dengan berat bola, maka timbangan 3 akan seimbang 
sempurna dengan berat 15 bola. Kemungkinan lain berat 2 balok dan 1 bola setara dengan berat 1 balok, 2 tabung dan 2 bola.

Berdasarkan pemaparan siswa kepada peneliti dalam menjawab soal nomor 8.B yang mengukur kemampuan penalaran matematis terkait indikator menyatakan ide matematis dari gambar yang disajikan, disimpulkan bahwa kemampuan penalaran matematis siswa dimulai dari tahapan melakukan penalaran dengan dugaan awal menarik kesimpulan berat 1 bola, 1 tabung dan 1 balok, kemudian tahapan selanjutnya siswa membuat perkiraan awal dengan mengaitkan konsep yang dipahami sebelumnya. Berikutnya siswa merencanakan penyelesaian dan melakukan rencana penyelesaian dengan membuat ekspresi jawaban kedalam bentuk gambar dan membuat kemungkinan-kemungkinan yang tepat berat 2 balok dan 1 bola agar seimbang.

\section{Kemampuan Representasi Matematis Siswa}

Hasil deskripsi analisis data diketahui bahwa kategori kemampuan representasi matematis siswa SMP di Kabupaten Indramayu berada pada kriteria sedang. Contoh jawaban dan respon siswa dalam menjawab soal yang diberikan berdasarkan indikator kemampuan representasi matematis siswa disajikan pada Gambar 4 dan Gambar 5.

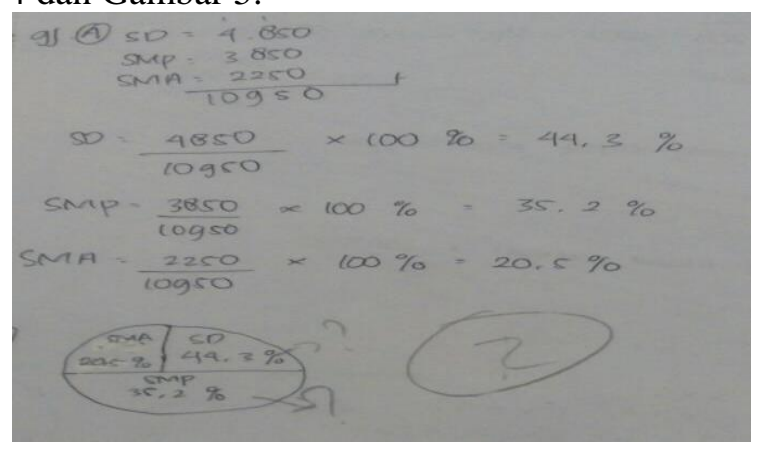

Gambar 4. Contoh Jawaban Siswa Soal Representasi Matematis

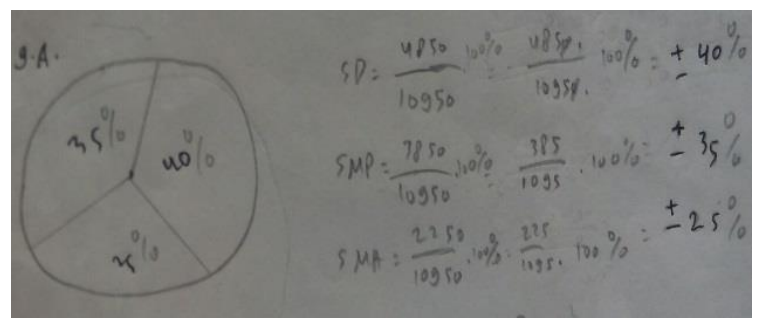

Gambar 5. Contoh Jawaban Siswa Soal Representasi Matematis

Pada Gambar 4 dan 5, terlihat contoh jawaban siswa yang menunjukkan bahwa siswa masih lemah dalam kemampuan representasi matematis dan siswa keliru dalam hal perhitungan matematika, meskipun mereka mampu menyajikan data dalam Gambar lingkaran. Soal yang mengukur kemampuan representasi matematis nomor 7.A, tentang indikator kemampuan siswa dapat menerjemahkan masalah matematika ke dalam bentuk representasi gambar, dari 390 siswa sampel sebanyak 132 atau sekitar 34\% siswa SMP di Kabupaten Indramayu mampu menggambar dengan benar tetapi kurang sesuai, lengkap dan detail dari informasi yang sudah diketahui. Dikarenakan banyak siswa yang lupa merepresentasikan masalah ke dalam bentuk gambar lingkaran dan juga ada beberapa siswa yang melakukan kesalahan hitung seperti gambar tersebut dalam mengkonversi satuan yang sudah diketahui kedalam bentuk persen atau derajat. Lebih lajut siswa yang membuat gambar dengan benar dan sesuai, lengkap serta detail sebanyak 11 atau 3\% siswa. Kemudian untuk siswa yang membuat gambar dengan benar dan sesuai, tetapi kurang lengkap serta detail dari informasi yang sudah diketahui sebanyak 90 atau $23 \%$ siswa, dan untuk siswa yang membuat gambar, tetapi tidak merepresentasikan masalah atau membuat gambar yang salah dan tidak ada hubungannya dengan soal sebanyak 106 atau $27 \%$ siswa, serta untuk siswa yang tidak membuat gambar atau tidak menuliskan apapun dilembar jawaban sebanyak 51 atau $13 \%$ siswa.

\section{SIMPULAN}

Berdasarkan hasil penelitian dan pembahasan, maka dapat disimpulkan bahwa kemampuan matematis siswa yang terdiri dari kemampuan penalaran dan representasi matematis siswa SMP di Kabupaten Indramayu secara keseluruhan termasuk dalam kategori sedang. Kemampuan penalaran matematis siswa SMP di Kabupaten Indramayu secara umum juga berada pada kategori sedang. Ditinjau dari strata sekolah, siswa dari sekolah strata tinggi memiliki nilai rata-rata skor yang lebih baik, jika dibandingkan siswa dari sekolah strata sedang maupun rendah. Begitupun siswa dari sekolah strata sedang memiliki nilai rata-rata skor yang lebih baik, daripada siswa sekolah strata rendah. Selanjutnya, kemampuan representasi matematis siswa SMP di Kabupaten Indramayu secara umum berada pada kategori sedang. Ditinjau dari indikator kemampuan representasi matematis, yakni kemampuan menerjemahkan masalah matematika ke dalam bentuk represen-tasi simbol aritmetika, merupakan capaian nilai ratarata skor tertinggi siswa, sedangkan capaian ni- 
Pythagoras, 12 (2), 2018 - 201

Absorin Absorin, Sugiman Sugiman

lai rata-rata skor terendah siswa, pada indikator kemampuan menerjemahkan masalah matematika ke dalam bentuk representasi tabel.

\section{DAFTAR PUSTAKA}

Anderson, D. R., Sweeney, D. J., \& Williams, T. A. (2010). Essential of statistics for business and economics (6 $6^{\text {th }}$ ed.). Southwestern, TX: Cengage Learning.

Bieda, K. N., Ji, X., Drweneke, J., \& Picard, A. (2013). Reasoning and proving opportunities in elementary mathematics textbooks. International Journal of Educational Research, 9(46), 1-10.

Brodie, K. (2010). Teaching mathematical reasoning in secondary school classroom. New York, NY: Springer.

Brumbaugh, D. K., Moch, P. L., \& Wilkinson, M. E. (2005). Mathematics content for elementary teachers. Marwah, NJ: Lawrence Erbaum.

Cai, J., Jakabcsin, M. S., \& Lane, S. (1996). Assessing students' mathematical communication. School Science and Mathematics, 96(5), 238-246.

Caprioara, D. (2015). Problem solving - purpose and means of learning mathematics in school. Procedia social and behavioural sciences, 191, 1859-1864.

Chambers, P., \& Timlinm, R. (2013). Teaching mathematics in the secondary school $\left(2^{\text {nd }}\right.$ Ed.). London: SAGE Publications.

Clements, D. H., \& Sarama, J. (2009). Learning and teaching early math: The learning trajectories approach. New York, NY: Routledge.

Dolinar, G. (2014). International Mathematics Olympiade (IMO 2014): Indonesia team result. Retrieved from https://imoofficial.org/team_r.aspx? code=IDN\&year $=2015$.

Dufresne, R. J., Gerace, W. J., \& Leonard, W. J (2004). Solving physics problems with multiple representations. Retrieved from http://www.srri.umass.edu/sites/srri/files/ dufresne-1997spp.pdf.

Ebel, R. L., \& Frisbie, D. A. (1991). Essentials of educational measurement. Englewood Cliffs, NJ: Prentice-Hall.

English, L. D. (2002). Handbook of international research in mathematics education. Mahwah, NJ: Lawrence Elbaum.

Farhan, M., \& Retnawati, H. (2014). Keefektifan PBL dan IBL ditinjau dari prestasi belajar, kemampuan representasi matematis, dan motivasi belajar. Jurnal Riset Pendidikan Matematika, 1(2), 227240. doi:https://doi.org/10.21831/jrpm.v1i2.26 78

Goldin, G. A., \& Kaput, J. J. (1996). A joint perspective on the idea of representation in learning and doing mathematics. In L. Steffe, P. Nesher, P. Cobb, G. A. Goldin, and B. Greer (Eds.), Theories of mathematical learning (pp. 397-430). Hillsdale, NJ: Erlbaum.

Goldin, G. A. (1998). Representational systems, learning, and problem solving in mathematics. Journal of Mathematical Behavior 17(2), 137-165.

Goldstein, E. B. (2011). Cognitive psychology: conecting mind, research, and everyday experience. Belmont, CA: Wadsworth.

Hwang, W. Y., Chen, N. S., Dung, J. J., \& Yang, Y. L. (2007). Multiple representation skills and creativity effects on mathematical problem solving using a multimedia whiteboard system. Eduacational Technology \& Society, 10(2), 191-212.

Kalathil, R. R., \& Sherin. M. G. (2000). Role of students' representations in the mathematics classroom. In B. Fihman \& S.O'connor-Divelbiss (Eds.). Fourth international conference of learning sience (pp.27-28). Mahwah, NJ: Erlbaum.

Kemendikbud. (2013). Peraturan Menteri Pendidikan dan Kebudayaan Nomor 66 Tahun 2013 tentang Standar Penilaian Pendidikan.

Kemendikbud. (2014). Peraturan Menteri Pendidikan dan Kebudayaan Nomor 58 Tahun 2014 tentang Kurikulum 2013 Sekolah Menengah Pertama/Madrasah Tsanawiah.

Kemendikbud. (2016). Peraturan Menteri Pendidikan dan Kebudayaan Nomor 21 Tahun 2016 tentang Standar Isi Pendidikan Dasar dan Menengah.

Kennedy, L. M., Tipps, S., \& Johnson, A. (2008). Guiding children's learning of 
Pythagoras, 13 (2), 2018 - 202

Absorin Absorin, Sugiman Sugiman

mathematics $\left(11^{\text {th }}\right.$ ed.) Belmont, CA: Thomson Higher Education.

Maarif, S. (2016). Improving junior high school students' mathematical analogical ability using discovery learning method. International Journal of Research in Education and Science (IJRES), 2(1), 114-124.

Moshman, D. (2015). Epistemic cognition and development: The psychology of justification and truth. New York, NY: Psychology Press.

Mullis, I. V. S., Martin, M. O., Foy, P., \& Arora, A. (2012). TIMSS 2011 international result in mathematics. Philadelphia, PA: TIMSS \& PIRLS International Study Center.

NCTM. (2000). Principles and standars for school mathematics. Reston, VA: Author.

Panasuk, R. M. (2010). Three phase rankin framework for assesing conceptual understanding in algebra using multiple representations. Education, 131(2), 235257.

Sabirin, M. (2014). Representasi dalam pembelajaran matematika. Jurnal Pendidikan Matematika IAIN Antasari, 1(2), 33-34.
Salkind, G. M. (2007). Mathematical representation. Retrieved from http://mason.gmu.edu/ gsalkind/portfolio/ products/857LitReview.pdf

Schwanke, B. (2008). Reasoning and proof (RAP) Journals: I am here. Research Projects, 36. Retrieved from http://digitalcommons.unl.edu/mathmidac tionresearch $/ 36$

Slavin, R. E. (2006). Educational psychology theory and practice ( $8^{\text {th }}$ ed.). Boston, MA: Allyn and Bacon.

Trianto, T. (2009). Mendesain model pembelajaran inovatif-progresif: Konsep, landasan, dan implementasinya pada kurikulum tingkat satuan pendidikan (KTSP). Jakarta: Kencana.

Van de Walle, J. A. Karp, K. S., \& BayWilliams, J. M. (2010). Elementary and middle school mathematics: teaching developmentally $\left(7^{\text {th }}\right.$ ed.). Boston, MA: Allyn and Bacon.

Wardhani, S., \& Rumiati, R. (2011). Instrumen penilaian hasil belajar matematika SMP: Belajar dari PISA dan TIMSS. Yogyakarta: PPPPTK Matematika. 